water, and chenically clean test tubes, may not be tention, having come up in America, it would certainly be sterilized and may not be clean in a bacteriological sense. interesting if Dr. Jones would repeat his experiments, Neither does he show that the turbidity could not also and, if from the same sample some well known bacterihave been due to the development and growth of the ologist, as for instance Professor Sternberg, or Ernst, germs.

The care and facilities for correct and unassailable investigations in these matters are such, that a lack or the slightest deficiency in either direction would make any conclusions certainly very doubtful, if not valueless. I bave myself kept such a Io per cent. solution for over five months, and without all the precautions necessary to prevent error, and the fluid has not become turbid, neither can the most careful examination show the presence of bacilli, dead or alive. I have kept half, I and 5 per cent. solutions without especial precantions for a number of weeks and they were perfectly clear at the end of such time.

Now as to the results of culture as obtained by Dr. Jones they are certainly remarkable, and it would be of the greatest interest if the report contained exact data of the steps and modes of his procedures, the way in which the culture media were prepared and kept after inoculations, and the time and the precautions under which he made his final examinations.

Dr. Jones being until now a stranger in the field of experimental bacteriology, it would not be unreasonabie to ask of him evidence for the remarkable statements which he makes, the more so inasmuch as men who have at their command the perfect equipments of bacteriological laboratories of Europe and other countries, and who have earned a world-wide reputation in this special field of scientific labor, and who have made similar investigations with Koch's lymph, have never found any fubercle bacilli capable of growth and multiplication, in that fluid.

'That the lympl contains dead or inert bacilli has been well known since the first introduction, and can be found especially in the sediment of occasional specimens, but heretofore, so far as I know, all culture and inoculation experiments have failed, and from the mode of preparation we must expect them to fail, if no germs are adinitted by error or oversight from without. These dead bacilli, are, however, not found so plentifully even in the sediment from a bottle of tuberculin as one might suppose from Dr. Jones' report; only here and there we find a bacillus in the field, and more often none at all. Their presence and inertness were known to Professor Koch and his associates, from the beginning has been referred to in the medical literature again and again, and the mode of preparation with prolonged exposure to intense heat of the fluid, and its preservation in glycerine after filtration through porcelain, is a sufficient guarantee that we have nothing to fear from them. Moreover, every vial before being sent out of the laboratory is especially tested and examined.

Dr. Jones should or could have known of the presence of inert bacilli, and of the negative experiments of other experiments before he undertook the examination of the vial submitted to him, and certainly before he published his report.

This question, which in Europe finds now no further at-

conld be induced to make control experiments, for such matters require to be definitely settled in the interest of science as well as that of the profession and patients.

It is certainly not intended that living tubercle bacilli should be contained in the tuberculin, and contrary to Dr. Jones' conclusions its action does not depend upon their presence, and this Dr. Jones must also have known . when he made his report. To me his concluding remarks are entirely unuecessary or bardly in good faith when he refers to the remedy as a secret medicine, Dr. Koch having given the temporary secret of its source and composition to the world before Dr. Jones came into possession of his vial. In the mean while those who use the remedy, if iufluenced by Dr. Jones' report, can make assurance doubly sure, by subjecting every solution for clinical use to prolonged boiling, which in no wise interferes with its action, and which $I$, and as far as I know, others who have applied it, have always done.

The addition of $1 / 2$ per cent. of carbolic acid can also be increased to any desired strength, as for instance, the so per cent. solution of tuberculin which we make from the original vial can contain 5 per cent., or 50 per cent. of carbolic acid may be added to the $1 \mathrm{ymph}$, and its I per cent. solution would then still only contain $1 / 2$ per cent. of carbolic acid as originally intended.

I here also found that tuberculin solution containing as much as $I$ or 2 per cent. of carbolic acid crystals are not specially painful or objectionable for hypodermic use. There can be no doubt, that the preparation of the tuberculin is in reliable hands, and that any findings justifying even the remotest suspicion as to the presence of active tubercle bacilli or other microörganisms would promptly lead to a revision of, and increased precautionary measures in its preparation, for indeed, it cannot be a matter of great difficulty to sterilize the remedy, and control experiments are daily being made in the laboratory of its production.

\section{Respectfully yours,}

KARI, VON RUCK, M.D.

Winyah Sanitarium, Asheville, N. C., Jume 3, I 89 I.

\section{Vote of the Mrissouri State Medical Associa- tion npon the "'Three Years Course."}

To the Editor:-As a part of the medical history of the West, the attitude of Missouri towards the great question of educational reform now agitated all over the country, must attract general interest. In THE JouRNAL, April Ir, 189I, an account was given of the history of the 'Three Years' obligatory Medical Course Bill in the Missouri Legislature: Indorsed in a memorial by I,700 doctors from all over the State, and by a large majority of the fourteen medical colleges chartered by the State, the Bill was unanimously recommended for passage by the committees of both House and Senate. The House passed the Bill by a vote of 85 to 22 ; it came before the 
Senate during the last hours of the session, and was defeated by a vote of 5 majority-a number of the Senators had already gone home, including friends of the Bill. A more flagrant violation of the principles of democracy and defiance of the will of the people, can hardly be instanced. At the annual meeting, May 2o, of the Missouri State Medical Association, the following resolution was introduced:

That the Association urge upon the State Board of Health that it define the statutory phrase "college in good standing" (as affecting the value of diplomas shown by applicants for license to practice medicine), to apply only to such colleges as require attendance upon three annual courses of lectures and clinics, of six months each, and that a copy of this resolution be sent to the Governor of the State, and to the State Board of Health.

This emphatic resolution was adopted by a vote almost unanimous, after all had time to take part in the discussion. 'Thus the representatives of the profession in Missouri have placed the State absolutely on record as desirous of the reform, and at the same time, they have put the stamp of their condemnation upon those who, through political juggling, have for the moment defrauded the State of necessary legislation, and betrayed the cause of science and of the people.

As proof of the complete unanimity of opinion in the State upon this subject, the homcopaths, in convention at Kansas City, April 22, passed a resolution identical in spirit with the one above given. The following is taken from the organ of the eclectics, the American Medical Joumal, St. Louis, April, is9r:

"In the senate it (the Three Years Bill) was defeated. This strange procedure may be understood in this way: If the Bill had passed the Senate, the Governor would have to sign or veto it. To veto would have incurred the displeasure of the great majority of physicians throughout the State, as well as that of the Senate. It would not have been the policy under the existing crisis. To sign the Bill would have offended some special friends."

That the influence of politics upon science is notoriously harmful, the events briefly summed up in this communication afford one more glaring illustration. Re spectfully, CHARLES A. TODD, M.D.

Chairman Com. Scientific Communications, Missouri State Medical Association.

St. Louis, June 6, I8gi.

\section{FOREIGN CORRESPONDENCE.}

\section{LETTER FROM LONDON.}

(FROM OUR OWN CORRESPONDENT.)

In several instances of late pneumonia has been most successfully treated by large doses of digitalis. By some medical men the expectant method of treating pneumonia is thought to be not only irrational, but even dangerous, and that the assumption that there is a definite cycle of progress in pneumonia is not warranted, and from experience obtained at the leading London hospitals, the disease may be jugulated or cut short by an energetic, rational mode of treatment, especially if the method is inaugurated at the onset of the disease, and that, finally, the claim is supported that the treatinent of pneumonia with large doses of digitalis promises better results than those obtainable by any other mode of procedure.

Dr. Steele has drawi attention to some useful precautions in the extraction of broken needles. He says that it is most unpleasant, after cutting and probing with the fingers and forceps, to be obliged to tell a patient that further attempts are useless, and that the fragment is still there. The plan he adopts is very simple, painless and reliable. In the first example which he gives, the patient, a young lady, had been unable to rest her left foot on the floor in walking for some weeks, as she had broken a needle into her left heel, and the slightest touch gave great pain. The point of entrance was visible in the middle line, over the os calcis. The end of the needle could be recognized through the skin, but the slightest pressure caused it to recede. Dr. Steele applied two thick felt corn plasters, one on the other, with the puncture occupying the central hole, and ordered the patient to walk freely and bear well upon the heel. This she did with perfect ease, and after ten days the needle presented and was easily withdrawn. Dr. Steele points out that the ball of the thumb and the wrist are not unfrequently punctured, and if the fragment enters oblique$1 y$, and lies close to arteries or nerves, and cannot be forced into prominence, attempts at extraction are undesirable, whereas by adopting this simple method, and producing pressure with an elastic ligature or light steel spring like a small truss, the fragment will work out, and not give pain from any knocks while under the skin.

Sir Arthur Mitchell and Dr. Buchan have discussed the influenza epidemic of the first three months of last year in a paper on "Influenza and Weather of London," published in the latest issue of the journal of the Scottish Meteorological Society. In the forty-five years from I 845 down to the end of March, I89o, the total number of deaths attributed to influenza registered in London was 4,690, an average of 104.2 per annum. It will surprise many that, strange as the epidemic was thought to be during its advance from the East towards the close of I 889 , deaths from this particular malady have been registered in London every year from 3845 . There were in all five epidemic outbursts, viz.: December, 1847 , to A pril, 1848, I,63I deaths; March to May, 185I, 258 deaths; January to March, 1855, I 30 deaths; November, 1857 , to January, I $85^{8}$, I23 deaths; and January to March, 1890 , 545 deaths. These visitations, therefore, cost 2,687 lives, leaving 2,003 to be distributed over the non-epidemic forty years. Latterly there was a great diminution of the yearly totals, the six years to the close of 1889 having only twenty.five deaths between them. The distribution of the deaths over the fifty-two weeks of the year shows that the numbers registered in the three months, December to February, were enormously in excess of those registered from May to September, so that there was a strongly-marked winter maximum, and a summer minimum. A secondary maximum was also shown towards the end of March and beginning of April. The authors enter into details connected with the five epidemics, and decide that, although the visits occur generally in the 